\title{
Orbital blowout fracture from nose blowing
}

\author{
Sam Myers, Daniel Bell
}

Department of Radiology, North Middlesex University Hospital NHS Trust, London, UK

\section{Correspondence to Dr Sam Myers,} sam.myers1@nhs.net

Accepted 12 June 2018
Check for updates

(C) BMJ Publishing Group Limited [2018]. No commercial re-use. See rights and permissions. Published by BMJ.

To cite: Myers S, Bell D. BMJ Case Rep Published Online First: [please include Day Month Year]. doi:10.1136/ bcr-2018-224633

\section{SUMMARY}

Orbital blowout fractures are nearly always caused by acute trauma. Non-traumatic cases of orbital blowout fractures have only been rarely described. In this case study, we discuss an orbital blowout fracture directly caused by nose blowing. The patient developed unilateral eye swelling and orbital emphysema. It is important for the clinician to investigate all suspected orbital blowout fractures with imaging and full ophthalmological examination regardless of a trauma history. Most cases of orbital emphysema resolve spontaneously, however one must always exclude compression of the central retinal artery. This may present as acute loss of vision and/or ophthalmoplegia.

\section{BACKGROUND}

Orbital blowout fractures are nearly always caused by trauma. Symptoms can include orbital pain and eye movement disorders. It is very rare to sustain an orbital blowout fracture from blowing one's nose. However, it is important that the clinician uses the clinical examination to guide them through to the diagnosis regardless of a history of trauma. Missing this diagnosis can be devastating for the patient, potentially leading to a permanent loss of vision.

\section{CASE PRESENTATION}

A 36-year-old woman presented to accident and emergency (A\&E) with sudden onset of bleeding from the left nostril 2 hours after blowing her nose. The epistaxis was self-limiting, however the patient developed left eye swelling. This was associated with a stabbing pain on the left side of the head and back, radiating to the left arm. There was no photophobia, or neck or chest pain.

The patient was fit and well with no previous medical history. She smoked 20 cigarettes per day.

On examination, there was gross swelling of the left eye. Visual acuity was $6 / 6$ in both eyes. Eye movements were normal with no diplopia. Pupils were equal and reactive to light. Crepitus was palpated along the left infraorbital rim. The patient was tachycardic; otherwise, the observations were normal.

\section{INVESTIGATIONS}

A non-contrast CT of the facial bones was requested (figures 1-2). This showed a fracture through the lamina papyracea of the medial left orbital wall with focal herniation of extraconal fat into the ethmoid air cells and slight tenting of the medial rectus muscle towards the defect. Otherwise, the extraocular muscles, optic nerve and globe were unremarkable. Extraconal orbital emphysema was present, with some gas tracking down through the soft tissues to lie inferior to the orbits within the buccal soft tissues.

Intermediate-density opacification of the left anterior and posterior ethmoid air cells was consistent with acute haemorrhage.

The other orbital walls were intact.

\section{Impression}

Acute fracture through the medial left orbital wall with secondary haemorrhage in the ethmoid air cells and mild herniation of extraconal fat without extraocular muscle herniation.

\section{DIFFERENTIAL DIAGNOSIS}

The most important differential to exclude in acute unilateral eye swelling is orbital cellulitis. This may present with pain on eye movement, ophthalmoplegia, visual loss, chemosis and fever. This needs urgent ophthalmological review.

Another differential is trauma to the eye. This must be excluded from the history and the eye examined for any foreign body.

\section{TREATMENT}

The patient was discharged on co-amoxiclav for outpatient follow-up with the maxillofacial surgery team.

She was advised to not blow her nose and to come back to A\&E if she had any fevers, eye pain or visual disturbances.

\section{OUTCOME AND FOLLOW-UP}

The patient was followed up in the maxillofacial surgery department 3 weeks later. She had not had any further severe pain, swelling or nosebleeds. She did experience some pain if she moved her face to the side quickly.

On extraorbital examination, there was no abnormality detected. There was no disturbance of sensation compared with the left cheek. No step defects were felt along the left maxilla, orbit or zygoma and no visual problems present.

Intraorally, all soft tissues were unremarkable in appearance with normal dental occlusion.

To allow healing, the patient was advised to not blow her nose, smoke or take part in contact sports.

\section{DISCUSSION}

Orbital emphysema is a benign condition that occurs following forceful air injection into the orbital soft tissue spaces. ${ }^{1}$ In the majority of cases, this occurs through a fracture of one of the orbital 


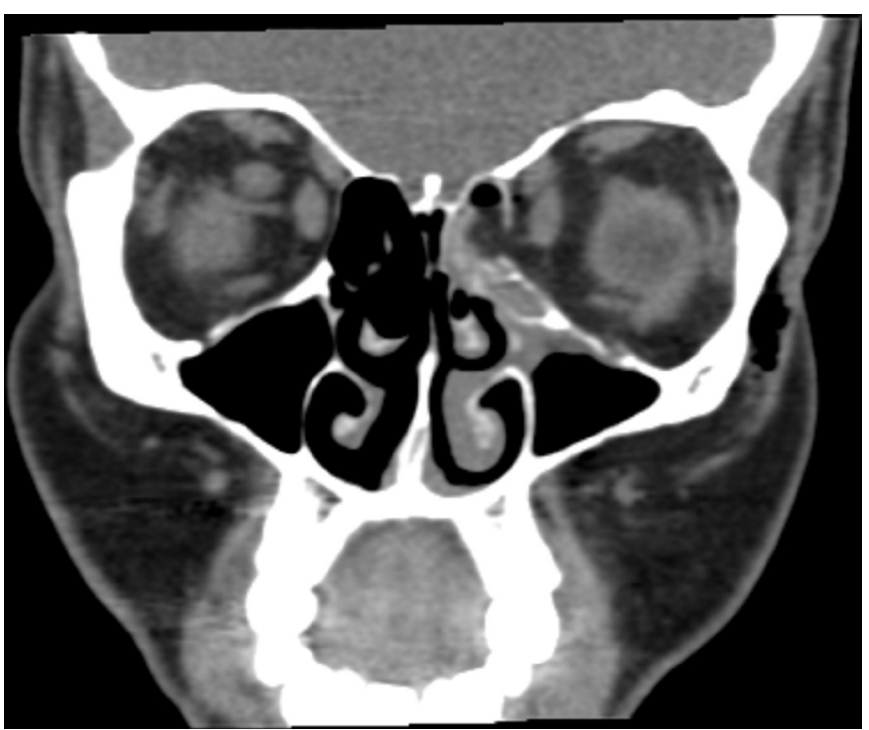

Figure $1 \mathrm{CT}$ facial bones, coronal view. On the left side is the herniation of the extraconal orbital fat through the fractured medial orbital wall into the ethmoidal air cells.

walls, allowing air entry. The orbital floor is usually the path of least resistance followed by the medial wall. ${ }^{2}$ There are only a few cases described in the literature of an orbital blowout fracture occurring without a history of trauma. ${ }^{3-7}$ Nose blowing can cause an increase in the intrasinus pressure causing barotrauma to the orbital bony wall. There is debate over the mechanism of this barotrauma. Some suggest that the increase in pressure is transmitted intrasinusally and thus fractures the orbital wall. Others suggest the fracture results from an increased intranasal pressure transmitted to the lamina papyracea.

Our patient had a fracture of the lamina papyracea which differs from other cases where the force of nose blowing was only enough to fracture the weaker orbital floor. ${ }^{6}$

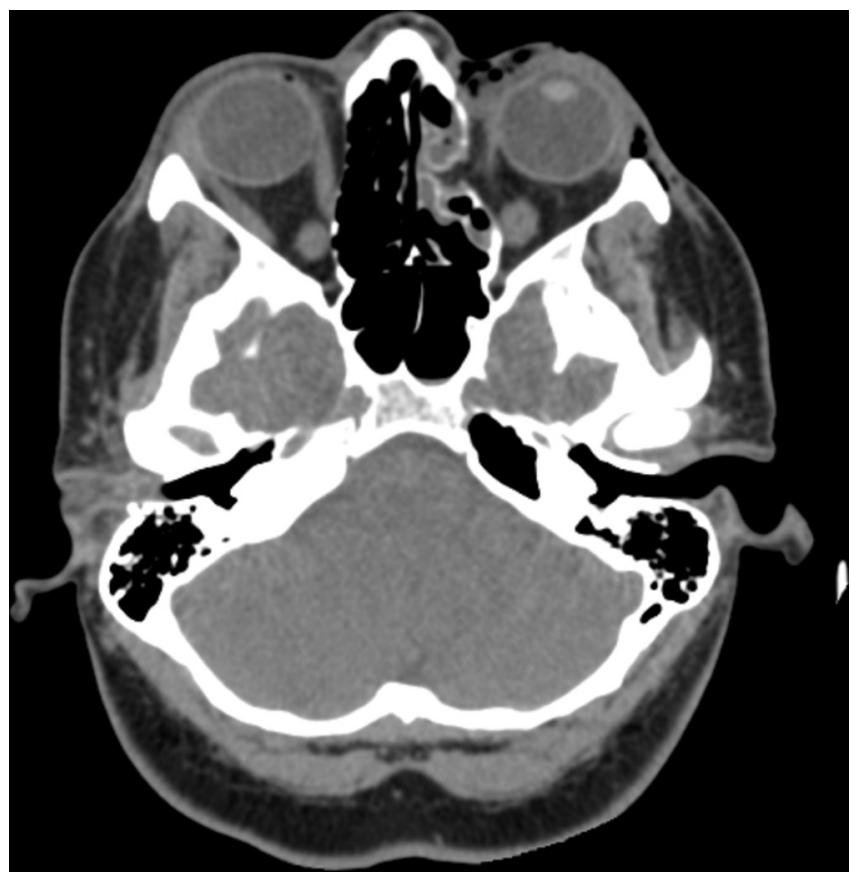

Figure 2 CT facial bones, axial view. On the left side is the herniation of the extraconal orbital fat through the fractured medial orbital wall into the ethmoidal air cells.

\section{Patient's perspective}

About a year ago, I was working as a domestic cleaner when I blew my nose. For a few seconds after, my vision went completely in both eyes. Then my left eye started to swell and my nose started to bleed. I thought nothing of it until a few hours later I could not see at all and I had pain on the left side of my head. I then went straight to A\&E.

They kept me in overnight and said I had a socket fracture in my left eye. I went to the Royal Free a few weeks after and they confirmed I had a fracture but only gave me painkillers.

I still get pain on the left side of my head everyday that can last from $30 \mathrm{~min}$ to a few hours. This can really affect my concentration throughout the day. Thank you to Dr Myers and Dr Bell for getting me a follow-up appointment with the specialist at the Royal Free to look into this.

\section{Learning points}

Non-traumatic orbital blowout fractures are well recognised but rare.

- Always request a CT and perform a full ophthalmological examination if an orbital blowout fracture is suspected.

- Orbital emphysema is nearly always self-limiting, but the clinician must exclude any signs of orbital compression.

Orbital emphysema normally resolves spontaneously after 2-3 weeks as systemic absorption takes place. ${ }^{8}$ Conservative management may include antibiotics, nasal decongestants and lifestyle advice on nose blowing. ${ }^{9}$

Orbital emphysema can rarely lead to complications; the most worrying of which is compression of the central retinal artery secondary to intraorbital mass effect, causing optic nerve ischaemia. This can present as loss of sight, proptosis and/or ophthalmoplegia. ${ }^{910}$ If there are signs of this pressure effect, it may be appropriate to drain the emphysema with a $24 \mathrm{G}$ needle or perform lateral canthotomy and cantholysis. ${ }^{11} 12$

We recommend that a CT and full ophthalmological examination occur for every clinically suspected orbital blowout fracture irrespective of a documented history of trauma.

Contributors SM is the corresponding author: contributed to conception, drafting and finalising of report. DB contributed to conception, drafting and finalising of report.

Funding The authors have not declared a specific grant for this research from any funding agency in the public, commercial or not-for-profit sectors.

Competing interests None declared.

Patient consent Obtained.

Provenance and peer review Not commissioned; externally peer reviewed.

\section{REFERENCES}

1 Gauguet JM, Lindquist PA, Shaffer K. Orbital emphysema following ocular trauma and sneezing. Radiol Case Rep 2008;3:124.

2 Suzuki H, Furukawa M, Takahashi E, et al. Barotraumatic blowout fracture of the orbit. Auris Nasus Larynx 2001;28:257e9-.

3 Oluwole M, White P. Orbital floor fracture following nose blowing. Ear Nose Throat $J$ 1996:75:169e70.

4 Watanabe T, Kawano T, Kodama $\mathrm{S}$, et al. Orbital blowout fracture caused by nose blowing. Ear Nose Throat J 2012;91:24e5.

5 Rahmel BB, Scott CR, Lynham AJ. Comminuted orbital blowout fracture after vigorous nose blowing that required repair. Br J Oral Maxillofac Surg 2010;48:e21-e22.

6 Jawaid MS. Orbital emphysema: nose blowing leading to a blown orbit. BMJ Case Rep 2015;2015:bcr2015212554 
7 Hwang K, Kim HJ. Medial orbital wall fracture caused by forceful nose blowing. J Craniofac Surg 2014;25:720-1.

8 Benharbit M, Karim A, Lazreq M, et al. Emergency treatment of post-traumatic orbital emphysema: A case report. J Fr Ophthalmol 2003;26:957-9.

9 Shah N. Spontaneous subcutaneous orbital emphysema following forceful nose blowing: treatment options. Indian J Ophthalmol 2007:55:395.
10 Linberg JV. Orbital emphysema complicated by acute central retinal artery occlusion: case report and treatment. Ann Ophthalmol 1982;14:747-9.

11 Benharbit M, Karim A, Lazreq M, et al. [Emergency treatment of post-traumatic orbital emphysema: a case report]. J Fr Ophtalmol 2003;26:957-9.

12 Reeves DL, Lucarelli MJ, Rose JG. Severe subcutaneous emphysema following orbital blowout fracture. Ophthalmic Plast Reconstr Surg 2005:21:465-7.

Copyright 2018 BMJ Publishing Group. All rights reserved. For permission to reuse any of this content visit http://group.bmj.com/group/rights-licensing/permissions.

BMJ Case Report Fellows may re-use this article for personal use and teaching without any further permission.

Become a Fellow of BMJ Case Reports today and you can:

- Submit as many cases as you like

- Enjoy fast sympathetic peer review and rapid publication of accepted articles

- Access all the published articles

Re-use any of the published material for personal use and teaching without further permission

For information on Institutional Fellowships contact consortiasales@bmjgroup.com

Visit casereports.bmj.com for more articles like this and to become a Fellow 